\title{
Pemberdayaan Masyarakat Desa Jungsemi di Masa Pandemi Covid 19 Melalui Pelatihan Pembuatan Hand Sanitizer dan Pelindung Wajah
}

\author{
Rosalina Ginting ${ }^{1)}$, Maftukin Huda ${ }^{1)}$, Valdyan Drifanda ${ }^{1)}$, Arief Rakhman Affandi ${ }^{2^{*}}$ ) \\ ${ }^{1)}$ Fakultas Pendidikan IImu Pengetahuan Sosial, Keolahragaan, dan Rekreasi, Universitas PGRI \\ Semarang \\ ${ }^{2)}$ Fakultas Teknik \& Informatika, Universitas PGRI Semarang \\ *email : gintingrosalina24@yahoo.co.id, maftukinhudah10@gmail.com, \\ valdyan.drifanda@gmail.com, ariefraffandi@upgris.ac.id
}

\begin{abstract}
During the coronavirus pandemic, there was a devastating effect on the social and economic sector and it was occurred in all segment of society. Social restrictions on some activities need to be done to prevent the potential spread of this corona virus. New adaptation patterns by engaging in healthy behaviors, such as washing hands with soap, avoiding crowds, or using masks or face shields, are quite effective to prevent transmission of the corona virus. When hand washing facilities are not available in any place, the use of hand sanitizers is expected to minimize transmission of the virus to others. In addition, hand sanitizer products can also be said to be quite practical in their use because they can be carried easily. Based on these reasons, the PPDM team collaborated with the Covid 19 Task Force and the Biology Education Laboratory of the Universitas PGRI Semarang to provide training in the manufacture of hand sanitizers and face shields for residents of Jungsemi Village. The aim of this training is to train villagers to be able to exploit the potential of this business during the pandemic. In addition, it also used to provide socialization about healthy behavior which will later become a new adaptation pattern during this pandemic.
\end{abstract}

Keywords : coronavirus, hand sanitizer, pandemic, training,

\begin{abstract}
Abstrak
Pada masa pandemi virus corona terjadi beberapa perubahan kondisi sosial dan ekonomi masyarakat. Pembatasan sosial pada beberapa kegiatan perlu dilakukan untuk mencegah menyebarnya virus corona ini. Pola adaptasi baru dengan melakukan perilaku sehat, seperti mencuci tangan dengan sabun, menghindari kerumunan massa, atau menggunakan masker atau pelindung wajah, merupakan cara yang cukup efektif untuk mencegah penularan virus corona. Penggunaan hand sanitizer diharapkan dapat meminimalisasi penularan virus kepada orang lain Ketika tidak tersedia fasilitas cuci tangan pada suatu tempat. Selain itu, produk hand sanitizer juga bisa dikatakan cukup praktis dalam penggunaannya karena dapat dibawa dengan mudah. Berdasarkan alasan tersebut, tim PPDM bekerja sama dengan Satuan Tugas Covid 19 dan Laboratorium pendiikan Biologi Universitas PGRI Semarang untuk memberikan pelatiha pembuatan hand sanitizer an pelindung wajah bagi warga Desa Jungsemi. Pelatihan pembuatan hand sanitizer dan pelindung wajah ini bertujuan melatih warga desa agar dapat memanfaatkan potensi usaha ini di masa pandemi. Selain itu, juga bertujuan untuk memberikan
\end{abstract}


sosialisasi kepada masyarakat mengenai perilaku sehat yang nantinya menjadi pola adaptasi baru di masa pandemi ini.

Kata kunci : virus corona, pelatihan, pandemi, hand sanitizer

\section{PENDAHULUAN}

Kemunculan virus baru yang muncul pada akhir tahun 2019 kemarin, menyebabkan dampak yang cukup banyak terhadap kondisi sosial dan ekonomi dunia. Bahkan di Indonesia, sudah hampir 72.000 orang telah terinfeksi oleh virus ini. Sebuah virus yang dikenal dengan nama Covid-19 atau corona memang merupakan sebuah wabah yang telah tersebar di hampir seluruh negara di dunia ini. Virus ini diketahui berasal dari Kota Wuhan di Negara Tiongkok pada bulan Desember 2019. Ada 6 jenis virus corona yang dikenal sejak tahun 1960, 4 jenis di antaranya yaitu OC43, 229E, NL63, and HKU1 menyebabkan pilek dan infeksi saluran gastrointestinal. Sedangkan 2 jenis lainnya yaitu Severe Acute Respiratory Syndrome Coronavirus (SARS-CoV) dan Middle East Respiratory Syndrome Coronavirus (MERS-CoV) bersifat pathogen dan dapat menyebabkan kematian manusia (Helmy et al, 2020). Berdasarkan hasil penelitian yang dilakukan oleh Zhou et al, (2020) diketahui bahwa virus corona ini memiliki sekuen genetic yang sama dengan virus yang berasal dari kelelawar. Penyebaran virus sangat cepat dikarenakan proses penularannya dari orang yang terinfeksi ke orang lain sangat mudah, seperti hal nya virus influenza. Perpindahan virus corona dari orang yang psotif ke orang lainnya adalah melalui droplet virus, kontak langsung dengan orang yang sakit, atau menyentuh barang yang sudah terkontaminasi virus Covid 19 (Gambar 1) (Chen and Chi,2020).

Ketika orang yang terinfeksi virus corona mengalami batuk-batuk, akan terbentuk dropletdroplet kecil yang dapat menempel pada orang-orang di sekitarnya. Droplet ini membawa virus yang nantinya akan masuk ke dalam tubuh orang yang sehat melalui perantara tangan atau bagian tubuh lainnya dari orang tersebut.

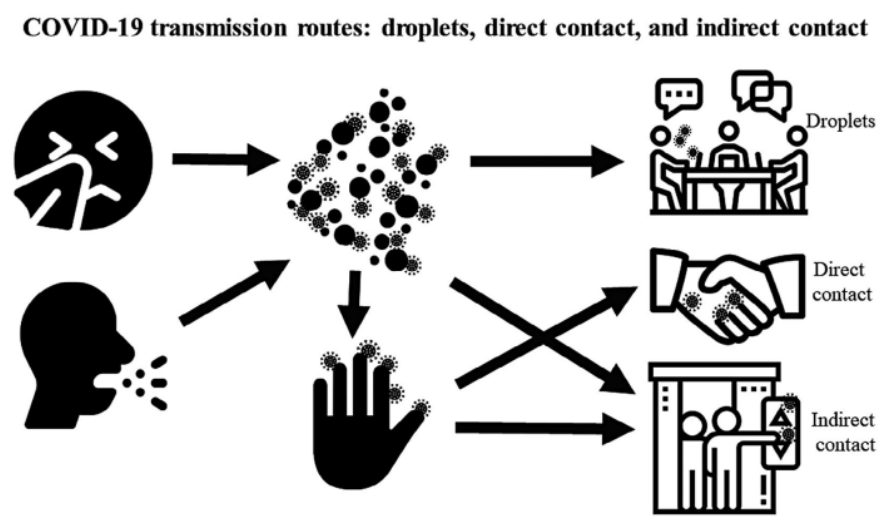

Gambar 1. Transmisi penularan virus Covid 19 ke orang lain (Chen and Chi,2020). 
Gejala umum yang ditimbulkan oleh virus ini pada diri seseorang yang telah terinfeksi yaitu, sesak nafas, batuk, suhu tubuh tinggi (demam), imunitas mengalami penurunan, dan beberapa gejala lainnya. Dalam rangka pencegahan penyebaran virus Covid 19 ini, Pemerintah telah memberikan himbauan kepada masyarakat untuk senantiasa berperilaku sehat dengan cara membiasakan diri untuk selalu cuci dengan sabun dan air mengalir, serta tidak berkumpul dengan banyak orang dalam suatu ruangan dikarenakan khawatir terinfeksi dari orang lain.

Dalam rangka membantu pencegahan tersebarnya virus ini di masyarakat, tim dari Program Pengembangan Desa Mitra (PPDM) Universitas PGRI Semarang (UPGRIS) melakukan beberapa kegiatan seperti pelatihan pembuatan hand sanitizer dan pelindung wajah di Desa Jungsemi Kecamatan Kangkung Kota Kendal Jawa Tengah. Hal ini bertujuan untuk membekali masyarakat untuk menghadapi wabah virus corona ini. Selain itu, diharapkan nanti akan muncul inisiatif dari warga untuk memproduksi produk yan cukup potensial untuk dikomersialkan pada masa pandemic ini sehingga dapat meningkatkan taraf perkeonomian masyarakat Desa Jungsemi.

\section{METODE PELAKSANAAN}

Beberapa kegiatan telah dilakukan oleh tim PPDM sesuai dengan rencana yang telah dipersiapkan sebelumnya. Koordinasi yang dilakukan dengan beberapa komponen perangakat desa, seperti Kepala Desa, Karang Taruna, dan kelompok PKK, bertujuan mensinergiskan program kerja pemerintah desa dengan program PPDM. Dengan demikian, sasaran kegiatan dapat tercapai sesuai target dan bermanfaat bagi masyarakat desa. Pelaksanaan pelatihan pembuatan hand sanitizer dan pelindung wajah (faceshield) bekerja sama dengan Satuan Tugas Covid-19 dan Laboratorium Pendidikan Biologi UPGRIS. Sasaran kegiatan pelatihan ini adalah anggota karang taruna dan kelompok PKK yang diharapkan mampu mengelola produk hasil pelatihan menjadi produk komersial yang bernilai jual tinggi. Selain mengadakan pelatihan, tim PPDM UPGRIS juga melakukan sosialisasi penggunaan masker dan pelindung wajah pada saat beraktivitas di luar ruangan, dimana terdapat banyak interaksi dengan orang lain di tempat tersebut.

\section{HASIL DAN PEMBAHASAN}

Pada masa pandemi, sebagian besar masyarakat merasa khawatir terhadap kondisi kesehatan mereka dan keluarganya. Bahkan ada beberapa keluarga yang mencoba untuk mengisolasi diri pada awal masa pandemi untuk menghindari tertular virus corona dari luar rumah mereka. Penambahan jumlah kasus penduduk yang terkonfirmasi positif mengalami peningkatan yang cukup tinggi (Gambar 2.). Pemerintah sedang berupaya untuk melakukan proses pencegahan penularan virus ini dengan 
menggunakan berbagai macam cara, mulai dari melakukan tes identifikasi orang yang tertular covid 19 secara massal bagi masyarakat. Orang terkonfirmasi positif akan diminta untuk melakukan isolasi diri pada tempat yang telah disediakan.

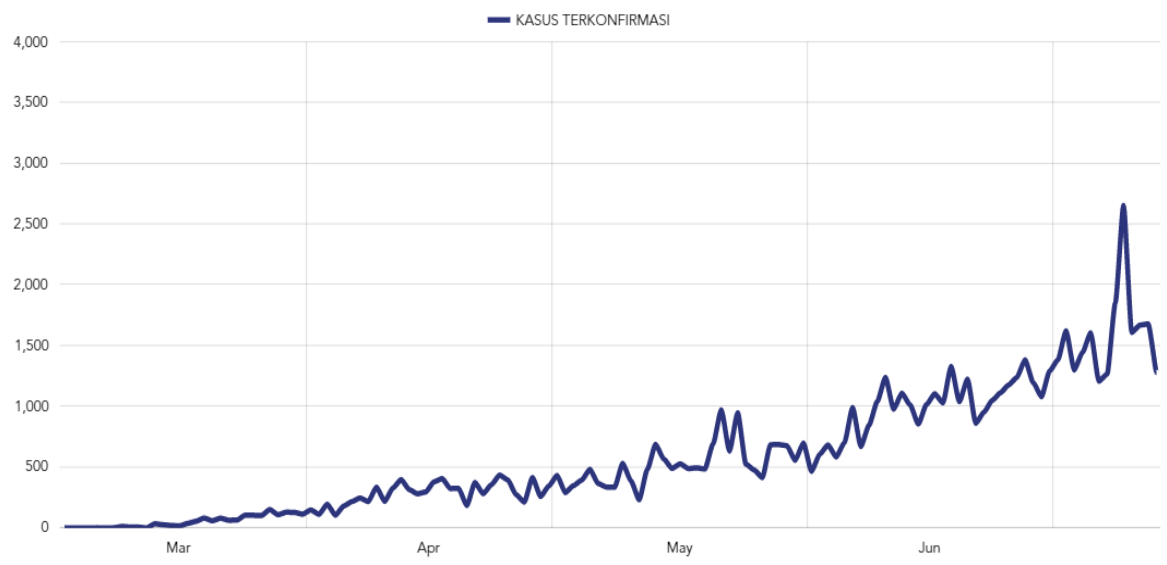

Gambar 2. Data perkembangan penduduk yang terkonfirmasi positif Covid 19 di Indonesia hingga tanggal 14 Juli 2020 (Gugus Tugas Covid 19, 2020).

Pencegahan penyebaran virus Corona di berbagai pelosok wilayah di Indonesia ini merupakan kewajiban bagi setiap warganegara. Wabah virus yang melanda negara ini telah menyebabkan terganggunya kondisi sosial dan ekonomi masyarakat. Beberapa kegiatan yang seharusnya diikuti oleh orang yang cukup banyak harus ditunda terlebih dahulu agar virus tidak mudah menyebar. Penggunaan masker di luar ruangan diwajibkan pada beberapa tempat tertentu. Perilaku hidup sehat senantiasa disosialisasikan untuk meningkatkan imunitas tubuh manusia. Beberapa perusahaan terpaksa memberhentikan karyawannya untuk menurunkan biaya produksi. Hal tersebut menyebabkan terjadinya perubahan pola hidup masyarakat selama pandemi berlangsung.

Salah satu contoh perilaku hidup sehat yang disosialisasikan oleh pemerintah adalah mencuci tangan dengan sabun atau dengan menggunakan hand sanitizer. Gerakan mencuci tangan sudah banyak dilakukan oleh masyarakat dengan menyediakan tempat untuk mencuci tangan di setiap rumah. Cara ini memang cukup efektif untuk membunuh virus yang menempel pada tangan dikarenakan sabun mengandung senyawa antimikroba. Namun cara ini dirasa kurang efektif ketika sedang pergi keluar rumah. Oleh karena itu, penggunaan hand sanitizer diharapkan mampu meminimalisasi jumlah mikroba yang ada di tangan, meskipun efektifitasnya lebih rendah dibandingkan sabun. 
Proses pembuatan hand sanitizer dapat dikatakan sangat mudah. Produk hand sanitizer dibuat dengan menggunakan beberapa komponen seperti alkohol, air aquades, senyawa antimikroba, dan bahan tambahan lainnya. Komposisi bahan harus disesuaikan dengan aturan dari WHO agar aman untuk digunakan dan efektif membunuh mikroba yang ada di tangan. Kegiatan pelatihan ini di awali dengan peragaan cara membuat hand sanitizer oleh tim dari Laboratorium Pendidikan Biologi UPGRIS (Gambar 3). Pada kesempatan berikutnya, pelatihan proses pembuatan pelindung wajah dibantu oleh tim Satgas Covid 19 dari Universitas PGRI Semarang. Pelaksanaan kegiatan ini diikuti oleh sekitar 15 orang perwakilan dari Karang Taruna dan kelompok PKK. Perwakilan peserta pelatihan ini diharapkan dapat meneruskan informasi yang didapat pada saat kegiatan berlangsung kepada anggota lainnya.

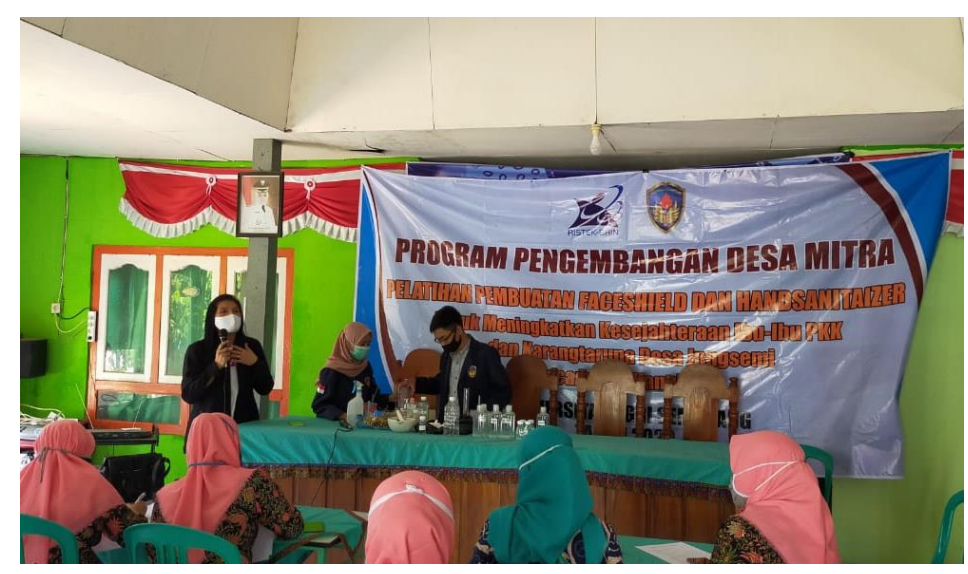

Gambar 3. Kegiatan Pembuatan Hand sanitizer di desa Jungsemi Kabupaten Kendal

Pada beberapa penelitian diketahui bahwa virus dapat diinaktivasi dengan menggunakan senyawa tertentu. Beberapa jenis desinfektan, seperti soium hipoklorit (0,1-0,5\%), etanol (62-71\%), atau hidrogen peroksida $(0,5 \%)$, ata menggunakan sinar ultraviolet dapat menurunkan konsentrasi virus secara efektif (Cirrincione et al, 2020). Komposisi hand sanitizer hasil produksi tim Satgas Covid 19 UPGRIS terdiri dari larutan alkohol 70\%, air aquades, gliserin, senyawa hidrogen peroksida $\left(\mathrm{H}_{2} \mathrm{O}_{2}\right)$, parfum (pewangi), dan beberapa komponen lainnya Larutan alkohol memiliki kemampuan bektersidal yang cukup kuat. Larutan hidrogen peroksida $\left(\mathrm{H}_{2} \mathrm{O}_{2}\right)$ merupakan senyawa oksidator yang cukup kuat dan memiliki sifat antimkroba yang cukup tinggi, terutama pada bakteri anaerob. Hidrogen peroksida akan terurai menjadi $\mathrm{H}_{2} \mathrm{O}$ dan $\mathrm{O}_{2}$ sehingga meningkatkan konsentrasi $\mathrm{O} 2$ di lingkungan. Kadar $\mathrm{O}_{2}$ yang diserap oleh mikroba menjadi lebih tinggi namun hal tersebut akan menyebabkan $\mathrm{O}_{2}$ berubah menjadi zat yang beracun yaitu superoksida. Senyawa ini akan mengoksidasi komponen fosfolipid yang tekandung dalam membran sel mikroba sehingga menyebabkan kerusakan pada komponen tersebut. Bahan ini dapat diganti dengan senyawa lain yang memiliki kemampuan antiseptik yang cukup tinggi 
seperti ekstrak rempah atau bahan lainnya. Gliserin berfungsi sebagai pelembab kulit sehingga penggunaan hand sanitizer tidak menyebabkan kulit menjadi kering.

Proses pembuatan hand sanitizer ini dimulai dengan mempersiapkan beberapa peralatan seperti gelas kimia, gelas ukur, dan batang pengaduk. Setelah itu, larutan alkohol diambil sebanyak $750 \mathrm{~mL}$ dengan menggunakan gelas ukur kemudian dimasukkan ke dalam suatu wadah gelas kimia steril. Begitu pula dengan larutan $\mathrm{H}_{2} \mathrm{O}_{2}$ dan gliserin. Proses pengadukan selalu dilakukan pada setiap penambahan bahan agar dapat tercampur dengan sempurna menjadi larutan yang homogen. Tahap terakhir dalam pembuatan hand sanitizer sederhana ini adalah menambahkan pewangi (parfum) dan air aquades ke dalam campuran bahan sebelumnya. Setelah bahan dimasukkan semua dilakukan proses pengemasan ke dalam wadah botol steril agar dapat bertahan lebih lama (Gambar 4).

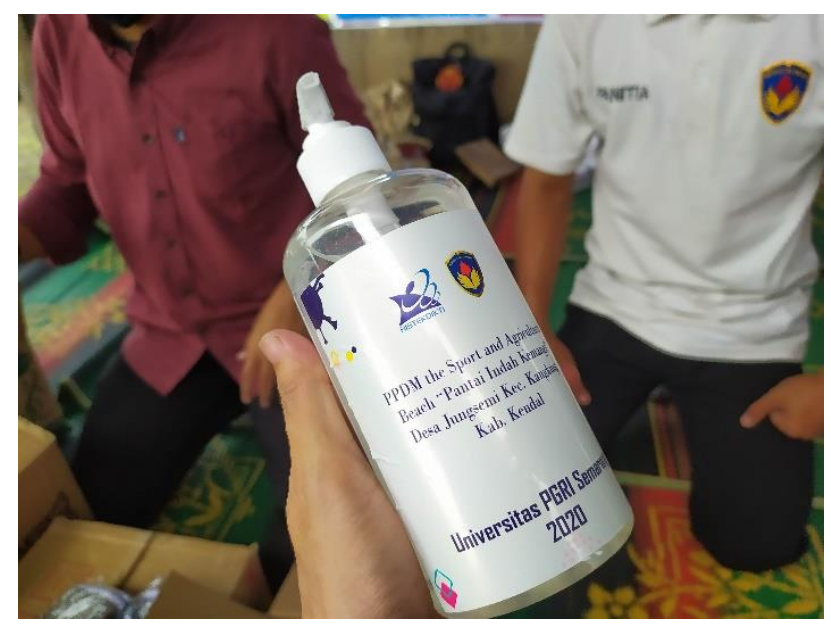

Gambar 4. Produk hand sanitizer pelatihan PPDM dengan kelompok Karang Taruna dan PKK desa Jungsemi.

Pelatihan ini bertujuan untuk memberikan wawasan kepada warga masyarakat mengenai proses pembuatan hand sanitizer sehingga dapat dijadikan sebagai salah satu usaha kreatif di masa pandemi ini. Dengan semakin banyaknya orang yang membutuhkan hand sanitizer, diharapkan muncul wirausahawan baru di Desa Jungsemi yang menghasilkan produk ini, baik untuk kebutuhan masyarakat Desa Jungsemi atau diperjualbelikan keluar daerah.

Salah satu alat pelindung diri (APD) yang juga dianjurkan digunakan oleh masyarakat, selain masker, adalah pelindung wajah (face shield). Pelindung wajah ini berfungsi mencegah droplet yang mengandung virus menempel di wajah kita sehingga kemungkinan tertularnya virus sangat sedikit. Pelindung wajah yang digunakan sebaiknya bisa menutupi seluruh wajah dan nyaman untuk dipakai dalam waktu yang cukup lama. Pada pelatihan pembuatan pelindung wajah, tim PPDM berusaha untuk menghasilkan produk pelindung wajah dengan menggunakan bahan yang mudah didapat di 
desa dan harganya tidak terlalu mahal. Beberapa bahan yang dapat digunakan dalam proses pembuatan pelindung wajah ini antara lain plastik mika tebal, busa, klip kancing, dan tali karet. Beberapa persyaratan dalam pembuatan pelindung wajah yaitu terbuat dari plastik bening dan memberikan visibilitas yang baik untuk pemakainya dan pasien, Pita yang bisa diatur agar pas di kepala dan pas di dahi, tahan kabut (lebih disukai), sepenuhnya menutupi sisi dan panjang wajah, dapat digunakan kembali (terbuat dari bahan yang dapat dibersihkan dan didesinfeksi) atau sekali pakai (Nugroho et al, 2020). Penggunaan bahan yang berkualitas dan mudah didapat ini bertujuan agar memudahkan masyarakat memproduksi pelindung wajah ini. Sosialisasi mengenai prosedur atau protokol kesehatan saat pandemi covid 19 kepada masyarakat Desa Jungsemi juga telah dilakukan bekerja sama dengan pemerintah desa (Gambar 5). keberlanjutan kegiatan setelah pelatihan diharapkan terus dilakukan agar dapat memenuhi kebutuhan desa dan meningkatkan perekonomian masyarakat.

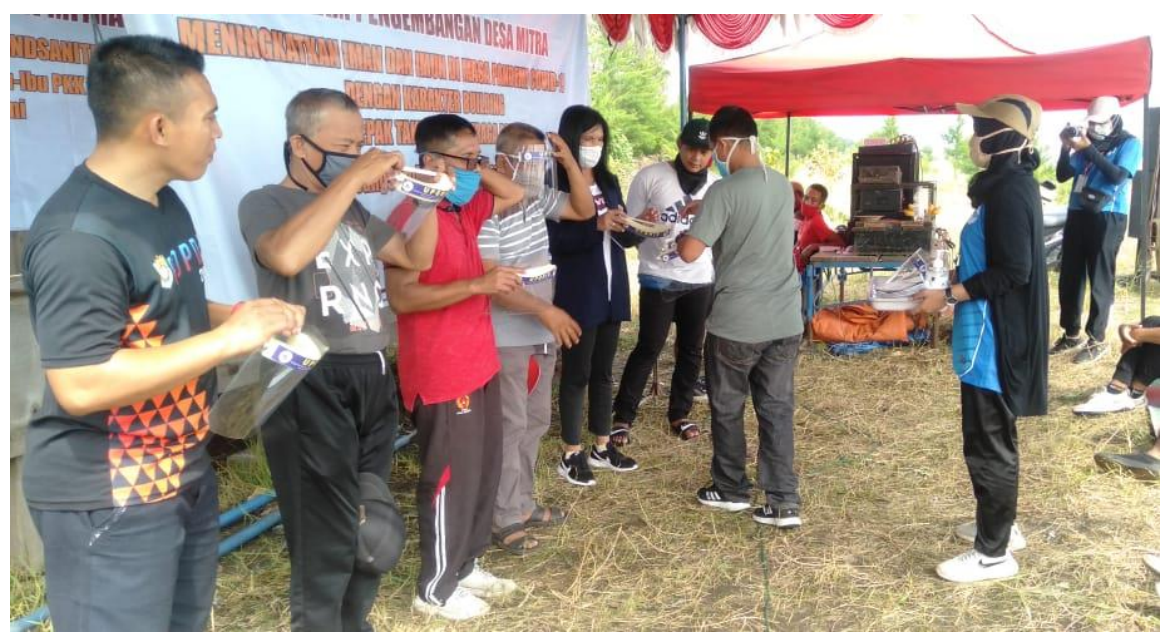

Gambar 5. Sosialiasi penggunaan masker \& pelindung wajah saat beraktivitas di luar ruangan oleh pemerintah desa dan tim PPDM

\section{UCAPAN TERIMA KASIH}

Penulis mengucapkan terima kasih kepada pihak yang telah memberi dukungan dana pelaksanaan pengabdian ini, yaitu dari Kementerian Pendidikan dan Kebudayaan Negara Republik Indonesia

\section{PENUTUP}

Pelatihan pembuatan hand sanitizer dan pelindung wajah telah dilaksanakan dengan lancar. Pemilihan bahan yang berkualitas dan mudah didapatkan merupakan stategi yang cukup tepat dalam proses produksi kedua bahan tersebut. Hasil dari pelatihan ini diharapkan dapat memberikan 
wawasan bagi masyarakat sehingga nantinya akan muncul ide kreatif untuk memproduksi dan memasarkan produk tersebut ke luar daerah.

\section{DAFTAR PUSTAKA}

Chen, C.-C. and Chi, C.-Y. (2020), Biosafety in the preparation and processing of cytology specimens with potential coronavirus (COVID-19) infection: Perspectives from Taiwan. Cancer Cytopathology, 128: 309-316. doi:10.1002/cncy.22280

Cirrincione L, Plescia F, Ledda C, Rapisarda V, Martorana D, Moldovan RE, Theodoridou K, Cannizzaro E. COVID-19 Pandemic: Prevention and Protection Measures to Be Adopted at the Workplace. Sustainability. 2020; 12(9):3603. https://doi.org/10.3390/su12093603

Gugus Tugas Covid 19 RI. 2020. Peta Perkembangan Kasus Terkonfirmasi Positif Covid 19 Nasional Per Hari. Di akses pada tanggal 14 Juli 2020 jam 08.00 https://covid19.go.id/peta-sebaran

Helmy YA, Fawzy M, Elaswad A, Sobieh A, Kenney SP, Shehata AA. The COVID-19 Pandemic: A Comprehensive Review of Taxonomy, Genetics, Epidemiology, Diagnosis, Treatment, and Control. Journal of Clinical Medicine. 2020; 9(4):1225. https://doi.org/10.3390/icm9041225

Nugroho CB, Ismail M, Sagoro G, Maskarai A, Ghozali MS, Asrafi, Satoto SW, Saputra R, Rusdwinanto CD, Sriyanto, Prasetyo NA, Antartika MP. 2020. Desain dan Pembuatan Faceshield Sebagai Alat Perlindungan Diri Penyebaran Covid19. Abdimas-Polibatam, Vol. 2 (1) Hal 1-16

Zhou, P., Yang, X., Wang, X. et al. A pneumonia outbreak associated with a new coronavirus of probable bat origin. Nature 579, 270-273 (2020). https://doi.org/10.1038/s41586-020-2012-7 